\section{FIRST ISOLATION OF VIBRIO VULNIFICUS CAUSING SEPSIS IN Santa Catarina, Brazil}

\author{
Primeiro isolamento de Vibrio Vulnificus causando \\ SEPSE em SANTA Catarina, BRASIL
}

\author{
Bruna Gerardon Batista ${ }^{1}$, Sidnei Alves dos Santos Júnior², \\ Alzira Resende do Carmo Aquino ${ }^{3}$, Rodrigo Argenta ${ }^{2}$
}

\begin{abstract}
Vibrio vulnificus is a bacterium present in natural marine environments that causes infections in immunocompromised people. Sepsis in humans caused by this microorganism is usually accompanied by bullous skin lesions. In the present study we report a case of infection caused by this bacterium affecting a diabetic man, 74 years old, who fell overboard and hurt his leg. The identification of the $V$. vulnificus was made in the blood culture sample. This is the first report of isolation of $V$. vulnificus in Santa Catarina, Brazil, showing the dissemination of this bacterium in warm seawater over the world.
\end{abstract}

Keywords: Vibrio vulnificus; infection; immunocompromised; seawater

\section{RESUMO}

Vibrio vulnificus é uma bactéria que se desenvolve em ambientes marinhos naturais e causa infecção em pessoas imunocomprometidas. Sepse em humanos causada por esse microrganismo é geralmente acompanhada por lesões bolhosas da pele. Relatamos um caso de infecção causada por esta bactéria que afetou um homem diabético, de 74 anos, que caiu ao mar e machucou a perna. A identificação do $V$. vulnificus foi feita na amostra de hemocultura. Este é o primeiro relato de isolamento de V. vulnificus em Santa Catarina, Brasil, elucidando a disseminação das bactérias de ambiente marítimo de água quente pelo mundo.

Palavras-chave: Vibrio vulnificus; infecção; imunocomprometido; água do mar

Vibrio vulnificus is a Gram-negative bacillus from natural marine environments ${ }^{1,2}$. Although it is a rare cause of illness, this bacterium may cause sepsis, which is life-threatening in patients with chronic health conditions, in those immunocompromised, and even in healthy people. People affected are usually taken to emergency departments for treatment, because the infection quickly becomes severe. Rapid diagnosis and administration of appropriate antibiotics are mandatory, since death can occur in 1 or 2 days after exposure to the bacteria. The two main modes of infection by $V$. vulnificus bacteria are consumption of raw or undercooked shellfish, primarily oysters, and exposure of open wounds to seawater (while fishing, boating, wading, swimming, or handling raw seafood ${ }^{2}$.

This is a halophilic microorganism whose growth is favored in waters with salinity from $0.7 \%$ to $1.6 \%$ and warm temperature ${ }^{2,3}$, such as other potentially pathogenic halophilic vibrios. V. vulnificus is part of normal marine flora and reaches sufficient concentrations to cause clinical illness only in the warm months of the year. This pathogen was the second most common Vibrio species isolated from human cases in Florida and evidence suggests that infections with $V$. vulnificus have increased in the United States, particularly in the Gulf Coast, as well as in the waters of Hawaii, Utah, and Massachusetts ${ }^{4-6}$.
Clin Biomed Res. 2016;36(3):165-167

1 Universidade Federal do Rio Grande do Sul (UFRGS). Porto Alegre, RS, Brasil.

2 Hospital Divina Providência. Porto Alegre, RS, Brasil.

3 Laboratório Unilab. Porto Alegre, RS, Brasil.

Corresponding author

Bruna Gerardon Batista bruna_batista@hotmail.com Faculdade de Farmácia, Universidade Federal do Rio Grande do Sul (UFRGS) Avenida Ipiranda, 2752.

90610-000, Porto Alegre, RS, Brasil. 
Among the pathogenic Vibrio species, V. vulnificus is the most virulent, causing the most severe disease, presenting sepsis and wound infections, which rapidly progress and may become fatal $\left.\right|^{5,7}$. The major determinant of virulence in $V$. vulnificus is its polysaccharide capsule, which can directly stimulate the release of inflammatory cytokines, such as alpha tumor necrosis factor (TNF- $\alpha)^{5}$.

The initial symptoms in humans are abdominal pain, nausea, myalgia, and fever. The development of sepsis is usually accompanied by bullous skin lesions especially on the extremities, as well as the occurrence of disseminated intravascular coagulation ${ }^{5,7}$. The increased virulence of vibrio in patients with iron overload can be explained by its ability to sequester iron from hemoglobin and $100 \%$ saturated transferrin. In cases of sepsis, mortality is higher than $50 \%$, reaching $90 \%$ in cases where septic shock occurs less than 12 hours after the onset of symptoms ${ }^{5,6}$.

\section{CASE REPORT}

R.S.D., 74 years old, diabetic, went to the emergency room reporting to have fallen overboard and hurt the region of the right leg about 48 hours previously. The patient presented bullous lesions, where it was possible to observe bloody discharge, and reported pain and dyspnea. Before the administration of antibiotics, blood and lesion samples were collected for analysis.

The identification and isolation of the $V$. vulnificus in the laboratory was made in two samples of blood culture which were positive in 24 hours of incubation. The gram stain disclosed Gram-negative curved bacilli (figure 1). The samples were subcultured on MacConkey agar and blood agar and incubated at $35-37^{\circ} \mathrm{C}$. The blood agar presented growth after 24 hours (figure 2); growth on MacConkey was detected only after 48 hours of incubation. Growth on MacConkey agar was poor. The colonies presented a positive result for the oxidase test. The biochemical identification was carried out using the $\mathrm{API}^{\circledR}$ (bioMérieux) and conventional tests, using Kit for Enterobactérias ${ }^{\circledR}$ (Laborclin). The conventional tests revealed that the bacterium was glucose and lactose fermenting, produced gas from glucose, being non-motile and lysine and ornithine decarboxylase positive. The result of the API ${ }^{\circledR}$ identified the sample as Vibrio vulnificus with $99 \%$ of probability.

The identification of Vibrio vulnificus was confirmed by mass spectrometry evaluation using the MALDI-TOF ${ }^{\circledR}$ (bioMérieux) system.

The susceptibility test was made by disk-diffusion on Mueller Hinton agar according to Methods for Antimicrobial Dilution and Disk Susceptibility Testing

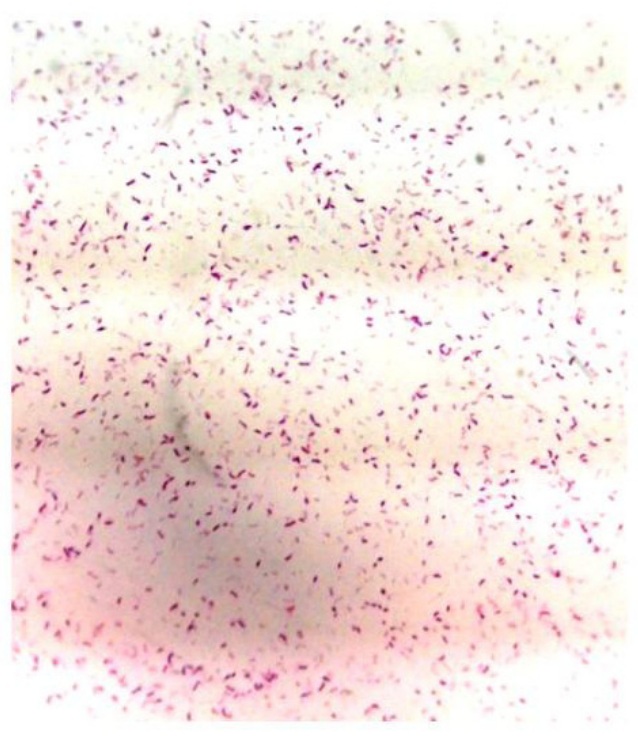

Figure 1: Gram stain of the colonies.

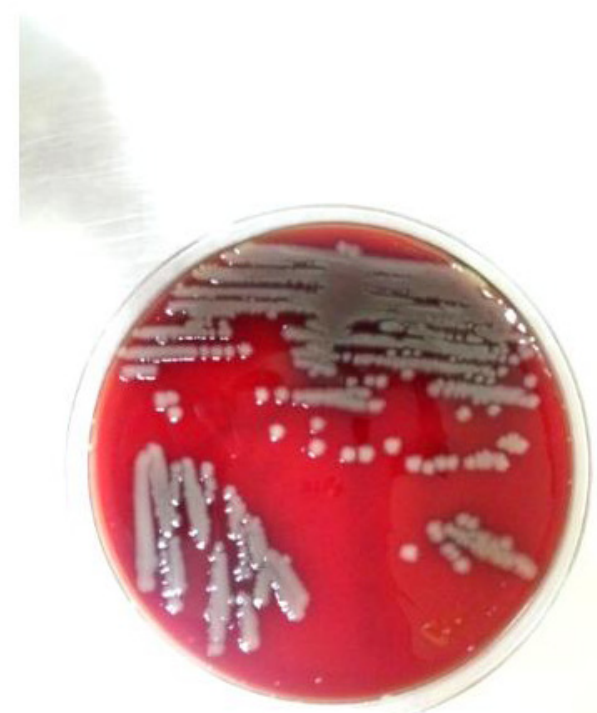

Figure 2: Growth on blood agar.

of Infrequently Isolated or Fastidious Bacteria from $\mathrm{CLSI}^{8}$, using ciprofloxacin $(5 \mu \mathrm{g})$, cephalosporins $(30 \mu \mathrm{g})$, carbapenems $(10 \mu \mathrm{g})$, and polymyxin B. The bacterium was resistant only to polimixin $B$.

\section{DISCUSSION}

This is the first report of isolation and identification of $V$. vulnificus from an infection acquired in the coast of Santa Catarina, Brazil, showing the dissemination of the bacteria over the world. Ramos et al. ${ }^{10}$ 
examined 60 seawater samples collected from South Bay near the Santa Catarina Island, Brazil, and found $44(73.3 \%)$ potentially pathogenic Vibrio spp., among which $V$. vulnificus corresponded to $8(13.3 \%)$ isolates. According to the present study, we should alert sunbathers, particularly those who have predisposing factors, about the risk of infections acquired in the seawaters of Santa Catarina.

According to Stivers ${ }^{9} 90$ cases of infection caused by $V$. Vulnificus are reported per year in the United States, of which $66 \%$ were from consumption of seafood and $34 \%$ from wound infections, showing that infections originated from wounds are less frequent. Skin infections caused by this microorganism are characterized by intense erythema and bullous hemorrhagic lesions. It is estimated that $11 \%$ of infections caused by $V$. vulnificus, are due to exposed wounds directly, or indirectly, in seawater through accidents in a marine environment ${ }^{4}$.

Bisharat et al. ${ }^{1}$ analyzed cases of wound infection and bacteremia caused by V. vulnificus in 1997. Thirty-three cultures were obtained from wound and most of these were reported during the summer season. Four $(7 \%)$ patients had necrotizing fasciitis and $12(19 \%)$ had diabetes mellitus. Similarly to our study, the reported patient presented diabetes mellitus and showed injuries like necrotizing fasciitis; in addition he was infected in the summer, when the temperature favors the growth of $V$. vulnificus.

In this case report, we presented the event of bullous lesions that persisted during the treatment. At the end of the treatment the patient recovered; however, in a related study conducted by França et al. ${ }^{6}$ the patient died in the first 30 hours of hospitalization and the culture result was available three days post-mortem.

The case report shows the importance of prompt diagnosis and appropriate treatment for the good prognosis of infected patients.

\section{Acknowledgements}

We would like to thank the Central Laboratory of Santa Casa de Misericórdia de Porto Alegre for confirming bacterial identification.

\section{REFERENCES}

1. Bisharat N, Agmon V, Finkelstein R, Raz 4. Kumamoto KS, Vukich DJ. Clinical $\mathrm{R}$, Ben-Dror $\mathrm{G}$, Lerner L, et al. Clinical, epidemiological, and microbiological features of Vibrio vulnificus biogroup 3 causing outbreaks of wound infection and bacteraemia in Israel. Israel Vibrio Study Group. Lancet. 1999;354:1421-4.

2. Horseman MA, Surani S. A comprehensive review of Vibrio vulnificus: an important cause of severe sepsis and skin and soft-tissue infection Int J Infect Dis. 2011;15:e157-66.

3. Kuhnt-Lenz K, Krengel S, Fetscher S, Heer-Sonderhoff A, Solbach W. Sepsis with bullous necrotizing skin lesions due to vibrio vulnificus acquired through recreational activities in the Baltic Sea. Eur J Clin Microbiol Infect Dis. 2004;23:49-52. infections of Vibrio vulnificus: a case report and review of the literature. $J$ Emerg Med. 1998;16:61-6.

5. Mandell GL, Bennett JE, Dolin R. Principles and practice of infectious diseases. 6th ed. Philadelphia: Elsevier; 2012. p. 2545-6.

6. França JCB, Sanfelice E, Gentili A, Raboni SM, Polido D, Marques F. Vibrio vulnificus infection in Southern Brazil - Case report. An Bras Dertamol. 2013;88:424-6.

7. Murray PR, Baron EJ, Pfaller MA, Tenover FC, Yolken RH. Manual of clinical microbiology. 7th ed. Washington: American Society for Microbiology; 1999. 499 p.
8. Clinical and Laboratory Standards Institute. M45-P: methods for antimicrobial dilution and disk susceptibility testing of infrequently isolated or fastidious bacteria: proposed guideline. 3rd ed. Wayne: CLSI; 2005.

9. Stivers TL. Diagnosing and treating deadly Vibrio Vulnificus infection. J Emerg Nurs. 2008;34:139-41.

10. Ramos RJ, Miotto LA, Miotto M, Silveira N JR, Cirolini A, Silva $\mathrm{HS}$, et al. Occurrence of potentially pathogenic Vibrio in oysters (Crassostrea gigas) and waters from bivalve mollusk cultivations in the South Bay of Santa Catarina. Rev Soc Bras Med Trop. 2014;47:327-33.

Received: June 01, 2016 Accepted: Aug 15, 2016 